\title{
Simultaneous Determination of Captopril and Thioguanine in Pharmaceutical Compounds and Blood using Cathodic Adsorptive Stripping Voltammetry
}

\author{
Ali Asghar Ensafi* and Reza Hajian \\ College of Chemistry, Isfahan University of Technology, Isfahan, 84156-83111, Iran
}

\begin{abstract}
Apresentamos um procedimento altamente seletivo e sensível para a determinação simultânea de captopril e de tioguanina baseado em processo de redissolução catódica adsortiva dos complexos de $\mathrm{Cu}(\mathrm{I})$-captopril e de $\mathrm{Cu}(\mathrm{I})$-tioguanina em um eletrodo gotejante de mercúrio. Captopril e tioguanina foram pré-concentrados na superfície da gota do eletrodo de mercúrio usando $\mathrm{Cu}(\mathrm{II})$ como sensor e tempo de acumulação igual a $90 \mathrm{~s}$. Em seguida, os complexos pré-concentrados foram analisados por voltametria adsortiva de pulso diferencial catódica. $\mathrm{O}$ efeito de vários parâmetros na sensibilidade, tais como, pH, concentração de cobre, potencial de acumulação, tempo de acumulação e velocidade de varredura, na sensibilidade do método foram estudados. As condições ótimas para a determinação simultânea de captopril e de tioguanina foram: $\mathrm{pH}=3,5$, concentração de cobre(II) $=45,0 \mathrm{ng} \mathrm{mL}^{-1}$, potencial de acumulação $=-0,10 \mathrm{~V}$ e velocidade de varredura $=60 \mathrm{mV} \mathrm{s}^{-1}$. Nas condições ótimas e tempo de acumulação igual a $90 \mathrm{~s}$, os picos de corrente medidos em torno de $-0,15 \mathrm{~V} \mathrm{e}-0,40 \mathrm{~V}(v s$. Ag/AgCl) foram proporcionais às concentrações de tioguanina e de captopril nas faixas de 0,15-180 e 0,5-100 $\mathrm{nmol} \mathrm{L}^{-1}$. Os limites de detecção para tioguanina e captopril foram 0,08 e $0,3 \mathrm{nmol} \mathrm{L}^{-1}$, respectivamente. Os desvios padrões relativos para cinco replicatas de $20,0 \mathrm{nmol} \mathrm{L}^{-1}$ de captopril e de tioguanina foram $2,5 \%$ e 2,1\%. O método para a determinação de captopril e de tioguanina foi testado em amostras de misturas sintéticas, farmacêuticas e em soro humano, apresentando resultados satisfatórios.
\end{abstract}

A reliable, highly selective and sensitive procedure is presented for simultaneous determination of captopril and thioguanine based on cathodic adsorptive stripping of $\mathrm{Cu}(\mathrm{I})$-captopril and $\mathrm{Cu}(\mathrm{I})$ thioguanine complexes on a hanging mercury drop electrode. Captopril and thioguanine were preconcentrated onto the surface of hanging mercury drop electrode using $\mathrm{Cu}(\mathrm{II})$ as a suitable probe, with accumulation time of $90 \mathrm{~s}$. Then the preconcentrated complexes were analyzed by cathodic stripping differential pulse voltammetry. The effect of various parameters such as $\mathrm{pH}$, concentration of copper, accumulation potential, accumulation time and scan rate on the sensitivity were studied. The optimum conditions for simultaneous determination of captopril and thioguanine include $\mathrm{pH}=3.5,45.0 \mathrm{ng} \mathrm{mL}^{-1}$ copper(II) concentration, accumulation potential of $-0.10 \mathrm{~V}$ and scan rate of $60 \mathrm{mV} \mathrm{s}^{-1}$. Under the optimum conditions and for an accumulation time of $90 \mathrm{~s}$, the measured peak currents at about $-0.15 \mathrm{~V}$ and $-0.40 \mathrm{~V}(v s . \mathrm{Ag} / \mathrm{AgCl})$ are proportional to the concentrations of thioguanine and captopril over the ranges of $0.15-180$ and $0.5-100 \mathrm{nmol} \mathrm{L}^{-1}$, respectively. The limits of detection are 0.08 and $0.3 \mathrm{nmol} \mathrm{L}^{-1}$ for thioguanine and captopril, respectively. The relative standard deviations for five replicate analyses of $20.0 \mathrm{nmol} \mathrm{L}^{-1}$ captopril and thioguanine are $2.5 \%$ and $2.1 \%$, respectively. The method was applied to the determination of captopril and thioguanine in synthetic mixed samples, pharmaceutical samples and human serum with satisfactory results.

Keywords: captopril, thioguanine, copper(II), adsorptive cathodic stripping voltammetry

\section{Introduction}

Captopril, 1-[(2S)-3-mercapto-2-methylpropionyl]- $L$ proline (Scheme 1) is a synthetic dipeptide serving as an orally active inhibitor of the angiontensin-covering enzyme

*e-mail: ensafi@cc.iut.ac.ir and has been widely used as antihypertensive drug, ${ }^{1,2}$ and to moderate heart failure. ${ }^{3}$ Captopril is metabolized chiefly to disulphide conjugates with other sulfhydryl-containing molecules. Serious toxicity has occurred primarily when captopril was given in high doses to patients with collagen vascular disease or renal insufficiency. Minor toxic effects which are seen include altered sense of taste, allergic skin 
rashes, and drug fever, which may occur in as many as $10 \%$ of patients. 4,5

6-Thioguanine, 2-amino-7H-purine-6-thiol (Scheme 2) has been used in treatment of various types of tumors. It is well known that thiopurines inhibit the synthesis of DNA and RNA and have been used successfully in the treatment of acute leukaemia. ${ }^{6,7}$ Because of their ability to interact with genetic material in the cell, this substance has mutagenic or carcinogenic properties. Thus, work with this substance yields biologically harmful waste materials, and glassware and instruments become contaminated.

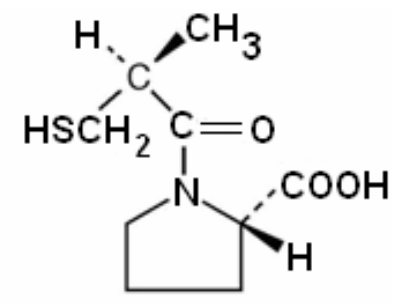

Scheme 1.<smiles>Nc1nc2nc[nH]c2c(=S)[nH]1</smiles>

Scheme 2.

Various instrumental methods have been developed for the determination of captopril including HPLC, ${ }^{8-15}$ spectrophotometry, ${ }^{7,16-19}$ fluorimetry, ${ }^{20,21}$ capillary electrophoresis ${ }^{22}$ and chemiluminescence methods. ${ }^{23}$ But all of the reported methods suffer from many interferences such as ascorbic acid, $\mathrm{Fe}^{2+}, \mathrm{Fe}^{3+}, \mathrm{NO}_{2}^{-}$and/or do not have good limit of detection $\left(>18 \mathrm{nmol} \mathrm{L}^{-1}\right)$. Only three methods have been reported for the determination of thioguanine..$^{24-26}$ Those reported methods could not measure thioguanine less than $120 \mathrm{nmol} \mathrm{L}^{-1}$. One of the important limitation of HPLC or spectrophotometric techniques is the fact that captopril and thioguanine lack sufficient UV absorption. So a pre- or post-column derivative procedure is normally required and these results increased cost and complication of analysis. Recently, Wang et al. ${ }^{27}$ have reported an electrochemical method based DNA sensor for the determination of thioguanine, with a limit of detection of $120 \mathrm{nmol} \mathrm{L}^{-1}$. The method was not used for real sample analysis.

Electrochemical methods allow the decrease of the analysis time comparing to the time consuming in spectrophotometric and chromatographic methods. The electrochemical detection of captopril has been reported using graphite ${ }^{28-30}$ and selective membrane electrodes as a working electrode..$^{30}$ Nevertheless, the sensitivity and reproducibility of the electrodes were not high because the surface of these electrodes was easy to contaminate by fouling caused by products and impurities. Other electrochemical techniques such as amperometry, ${ }^{31-33}$ square wave voltammetry ${ }^{2,33}$ and differential pulse stripping voltammetry ${ }^{34}$ were also used for the determination of captopril. But these methods suffer from relatively high limit of detection $\left(\sim 2.3 \mathrm{nmol} \mathrm{L}^{-1}\right)$, in addition to low sensitivity, long analysis time. On the other hand, the selectivity of those techniques was not studied.

A new combination dosage form of captopril and thioguanine is indicated for the treatment and management of hypertension and leukemia. ${ }^{26,28}$ According to our knowledge, there is no report for simultaneous determination of both drugs in biological fluids. Therefore, it is necessary to establish a new analytical method for their simultaneous determination.

The proposed method is a highly sensitive, simple, fast and accurate method with lower detection limits for simultaneous determination of captopril and thioguanine in tablets and blood. The method is based on cathodic adsorptive stripping of $\mathrm{Cu}(\mathrm{II})$-captopril and $\mathrm{Cu}(\mathrm{II})$ thioguanine complexes on a hanging mercury drop electrode (HMDE). Then the preconcentrated complexes were analyzed by cathodic stripping differential pulse voltammetry.

\section{Experimental}

\section{Chemicals}

All the chemicals were of analytical grade and were purchased from Merck (Darmstadt, Germany) unless otherwise stated. Doubly distilled water was used throughout. Captopril and thioguanine were purchased from Aldrich and Fluka companies, respectively.

Stock solution $\left(100 \mu \mathrm{g} \mathrm{mL}^{-1}\right)$ of $\mathrm{Cu}(\mathrm{II})$ was prepared by dissolving $0.0100 \mathrm{~g}$ of copper metal in $10 \mathrm{~mL}$ of $0.01 \mathrm{~mol} \mathrm{~L}^{-1} \mathrm{HNO}_{3}$ and diluted with water in a $100 \mathrm{~mL}$ volumetric flask.

A $1.0 \times 10^{-3} \mathrm{~mol} \mathrm{~L}^{-1}$ captopril solution was prepared daily by dissolving $0.0224 \mathrm{~g}$ captopril (97\%) in water and the solution was diluted to $100 \mathrm{~mL}$ with water in a $100 \mathrm{~mL}$ volumetric flask. The solution was kept in a refrigerator at $4{ }^{\circ} \mathrm{C}$ and in dark. More dilute solutions were prepared by serial dilution with water.

A $1.0 \times 10^{-3} \mathrm{~mol} \mathrm{~L}^{-1}$ thioguanine solution was prepared daily by dissolving $0.0174 \mathrm{~g}$ thioguanine $(96 \%)$ in water and the solution was diluted to $100 \mathrm{~mL}$ with water in 
a $100-\mathrm{mL}$ volumetric flask. The solution was kept in a refrigerator at $4{ }^{\circ} \mathrm{C}$ in dark. More dilute solutions were prepared by serial dilution with water.

Captopril tablets (Exir Pharmaceutical Co., Iran, labeled 25 and $50 \mathrm{mg}$ captopril per tablet) were purchased from Red Cross drug store in Isfahan. Thioguanine tablet (Glaxo Smith King, Italy, labeled $40 \mathrm{mg}$ thioguanine per tablet) was purchased from Red Cross drug store in Isfahan.

Britton-Robinson (B-R) buffers $\left(0.1 \mathrm{~mol} \mathrm{~L}^{-1}\right.$ in phosphate, acetate and borate) in the $\mathrm{pH}$ range of 2-9 were used, throughout.

\section{Apparatus}

Voltammetric measurements were carried out using a Metrohm instrument, Model 797 VA, computrace with stand three-electrodes containing a HMDE as a working electrode, a carbon rod as an auxiliary electrode and an $\mathrm{Ag} / \mathrm{AgCl}\left(3.0 \mathrm{~mol} \mathrm{~L}^{-1} \mathrm{KCl}\right)$ reference electrode.

A Pentium IV (2.0 MHz) computer controlled all of the setting and data processing.

A pH-meter (Corning, Model 140) with a double junction glass electrode was used to check the $\mathrm{pH}$ of the solutions.

\section{Preparation of real samples}

For preparation of tablets solutions, five tablets were mixed and powdered. A portion of the powder containing approximately $20 \mathrm{mg}$ of captopril and/or thioguanine was accurately weighted and then dissolved in $20 \mathrm{~mL}$ of water. After mixing completely, the mixture was filtered with an ordinary filter paper. Then the filtered solution was transferred into a $1000 \mathrm{~mL}$ volumetric flask and the solution was diluted to the mark with water.

Serum samples were obtained and stored frozen until the assay. Into each of 10 centrifugation tubes containing a certain concentration of captopril and/or thioguanine, $0.10 \mathrm{~mL}$ of the human serum sample was transferred, and then mixed well with $1.0 \mathrm{~mL}$ of methanol to precipitate the blood proteins. The precipitated proteins were separated by centrifuging of the mixture for $20 \mathrm{~min}$ at $4000 \mathrm{rpm}$. The clear supernatant layer was filtered through a $0.45 \mu \mathrm{m}$ millipore filter to produce protein-free human serum. The human serum sample was transferred into a $25 \mathrm{~mL}$ calibrated flask, completed to the volume with B-R buffer of $\mathrm{pH} 3.5$, and then introduced to the voltammetric cell.

Whole blood $(1.0 \mathrm{~mL})$, plus $1.5 \mathrm{~mL}$ water and $2 \mathrm{~mL}$ of $1 \mathrm{~mol} \mathrm{~L}^{-1}$ sulfuric acid were heated in a $10 \mathrm{~mL}$ polypropylene screw cap tube (Sarstedt, Germany) for $45 \mathrm{~min}$ at $100{ }^{\circ} \mathrm{C}$. The samples were centrifuged at 4000 rpm for $10 \mathrm{~min}$ and the supernatant $(2.5 \mathrm{~mL})$ was transferred to a new tube for precipitation with $23 \%(\mathrm{~m} / \mathrm{v})$ perchloric acid $(10 \mathrm{~mL})$. This solution was extracted with $1.0 \mathrm{~mL}$ dichloromethane and centrifuged for $10 \mathrm{~min}$ at $4000 \mathrm{rpm} .{ }^{26}$ Aqueous supernatant $(1.3 \mathrm{~mL})$ was transferred into a clean $12 \times 75 \mathrm{~mm}$ glass tube and aliquots of $0.1 \mathrm{~mol} \mathrm{~L}^{-1}$ sodium bicarbonate $(\mathrm{pH} 10.1)$ was added to adjust the solution $\mathrm{pH}$ to approximately 3.5 . Then $30 \mu \mathrm{L}$ of the supernatant was injected into the voltammetric cell.

\section{Recommended procedure}

For simultaneous determination of captopril and thioguanine, $25 \mathrm{~mL}$ of the supporting electrolyte solution (B-R buffer at $\mathrm{pH} 3.5$ ) containing $45.0 \mathrm{ng} \mathrm{mL}^{-1}$ copper(II) was pipetted into the electrochemical cell. The solution was purged with nitrogen gas for $4 \mathrm{~min}$. The adsorption potential at $-0.10 \mathrm{~V}$ vs. $\mathrm{Ag} / \mathrm{AgCl}$ was applied to a fresh HMDE and the adsorption were carried out in a stirred solution (200 $\mathrm{rpm}$ ) for a period of $90 \mathrm{~s}$. Then a differential pulse stripping voltammogram was recorded from 0.00 to $-0.50 \mathrm{~V}$ with a potential scan rate of $60 \mathrm{mV} \mathrm{s}^{-1}$ and pulse amplitude of $100 \mathrm{mV}$. After the background voltammogram was obtained $\left(\mathrm{Ip}_{\mathrm{b}}\right)$, aliquots of the sample solution containing a certain concentration of captopril and thioguanine were introduced into the cell while maintaining a nitrogen atmosphere above the solution. A differential pulse stripping voltammogram was recorded as described above to obtain the sample peak currents $\left(I p_{s}\right)$. The difference currents $\left(\operatorname{Ip}_{s}-I p_{b}\right)$ were considered as a net signal $(\Delta \mathrm{Ip})$. All data were obtained at room temperature. Calibration graphs were prepared by plotting the net peak currents versus captopril and/or thioguanine concentrations.

\section{Results and Discussion}

Captopril, 1-[(2S)-3-mercapto-2-methylpropionyl]- $L$ proline is a synthetic dipeptide and is a thiol. 6-Thioguanine, 2-amino-7H-purine-6-thiol is also a thiol compound that has been used in treatment of various types of tumors. Copper(II) can react with thiol (such as captopril and/ or thioguanine) to oxidize the thiol with formation of $\mathrm{Cu}(\mathrm{I})$-thiolate complexes. ${ }^{35}$ Figure 1 displays the cathodic stripping differential pulse voltammograms for the system. A blank solution (B-R buffer at $\mathrm{pH} 3.5$ plus $20 \mathrm{ng} \mathrm{mL}^{-1}$ copper(II)) does not show any peak current in potential range of -0.10 to $-0.40 \mathrm{~V}$ (Figure $1 \mathrm{a}$ ). A solution containing captopril and thioguanine (in the absence of copper(II)) in the buffer solution (Figure 1b) shows small peak currents that overlapped with each other in the potential of -0.32 and $-0.25 \mathrm{~V}$ for thioguanine and captopril, respectively. 
With the addition of $\mathrm{Cu}(\mathrm{II})$ to the solution of captopril and thioguanine, two large cathodic peaks were obtained (Figure 1c) in the potential ranges of -0.15 to $-0.25 \mathrm{~V}$ and -0.30 to $-0.40 \mathrm{~V}$, which are related to thioguanine and captopril, respectively. The peak currents were omitted without applying any accumulation time (Figure 1d). In addition, when $10 \mu \mathrm{g} \mathrm{mL}^{-1}$ of Triton $\mathrm{X}-100$ was added to the solution, each of the peak currents was reduced to $40 \%$ of its initial value. This phenomenon suggests that the complex was adsorbed before undergoing electrode reaction.

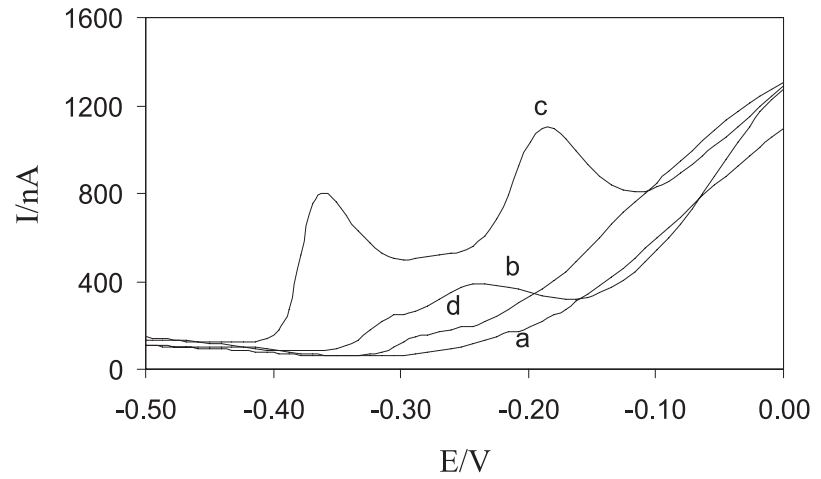

Figure 1. Differential pulse voltammograms of captopril-copper(I) and thioguanine-copper(I) systems: (a) $20 \mathrm{ng} \mathrm{mL}^{-1}$ copper(II) in B-R buffer $(\mathrm{pH}=3.5)$ after $90 \mathrm{~s}$ accumulation at $-0.10 \mathrm{~V}$ and scan rate of $60 \mathrm{mV} \mathrm{s}^{-1}$. (b) $50 \mathrm{nmol} \mathrm{L}^{-1}$ captopril and/or thioguanine in B-R buffer $(\mathrm{pH}=3.5)$ after $90 \mathrm{~s}$ accumulation time at $-0.10 \mathrm{~V}$; (c) b plus $20.0 \mathrm{ng} \mathrm{mL} \mathrm{m}^{-1}$ copper(II); (d) $\mathrm{c}$ without application of any accumulation time.

In order to obtain the coordination numbers $(\mathrm{m})$ and the formation constant $(\beta)$ of the complexes adsorbed on the surface of the electrode, the following equation can be used: 36,37

$$
1 / i_{p}=1 / i_{p, \max }+1 /\left(i_{p, \max } \beta c^{m}\right)
$$

where $i_{p}$ is the measured peak current, $i_{\mathrm{p}, \max }$ is the peak current when all the metal ions form the complex, $\beta$ is the formation constant of the complex and $\mathrm{c}$ is the concentration of the ligand. By plotting $1 / i p$ vs. $c^{-m}$ for different $m$ values, a straight line will be constructed for the corresponding complex. The results of our calculation shows that when $m=1$, a straight line with $r=0.9945$ is obtained for thioguanine (Figure 2a). A similar straight line with $r=$ 0.9953 is obtained for captopril at $m=1$ (Figure 2b). The results indicate that the compositions of the electroactive complexes on the surface of the mercury electrode are 1:1 (metal/ligand) for both thioguanine and captopril.

According to the above results, the reduced form of $\mathrm{Cu}(\mathrm{II})$ in the presence of the thiols $(\mathrm{Cu}(\mathrm{I}))$ makes
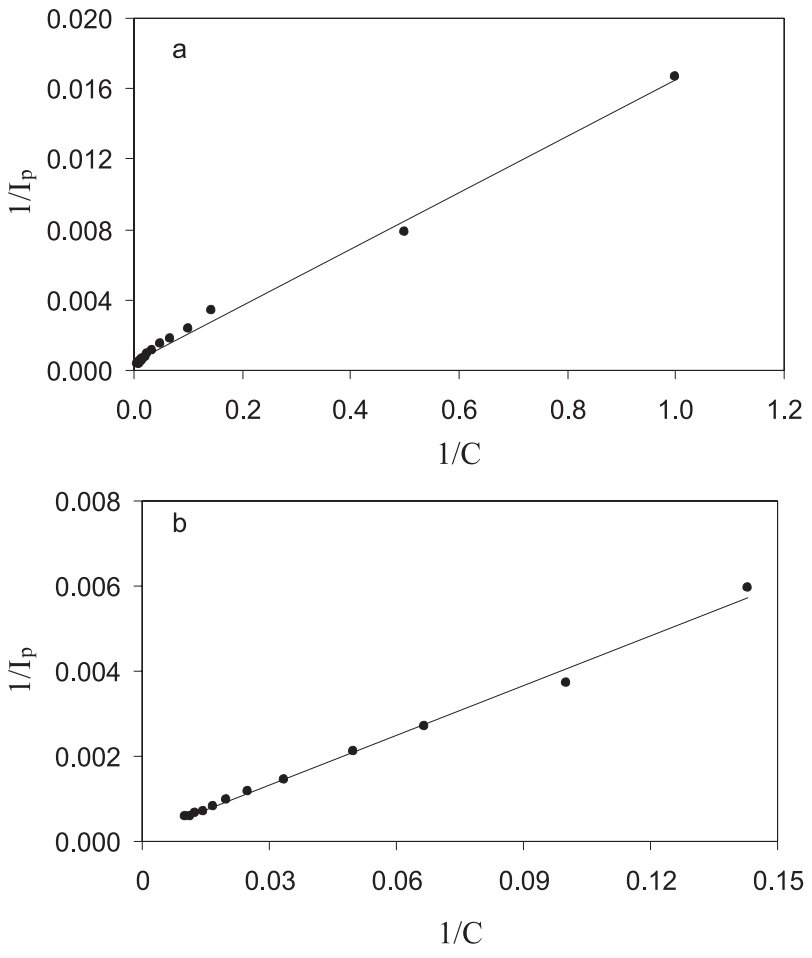

Figure 2. The plots of $1 / \mathrm{i}_{\mathrm{p}} v s \mathrm{C}^{-1}$ for (a) thioguanine and (b) captopril

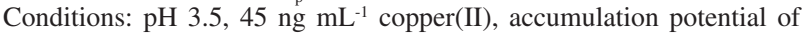
$-0.10 \mathrm{~V}$, accumulation time of $90 \mathrm{~s}$, and scan rate of $60 \mathrm{mV} \mathrm{s}^{-1}$.

complex with thioguanine and/or captopril in the solution. Then the complexes were adsorbed on the surface of the electrode by applying the accumulation potential during the accumulation time. The adsorbed complexes were reduced by scanning the potential from 0.00 to $-0.50 \mathrm{~V}$. The electrode processes can be summarized as follows:

$$
\begin{aligned}
& \mathrm{L}_{\text {red }}+\mathrm{Cu}(\mathrm{II}) \longrightarrow \mathrm{L}_{\mathrm{ox}}+\mathrm{Cu}(\mathrm{I}) \\
& \mathrm{nL}_{\mathrm{ox}(\text { (sol. })}+\mathrm{Cu}(\mathrm{I}) \rightleftarrows\left(\mathrm{L}_{\mathrm{ox}}\right)_{\mathrm{n}} \mathrm{Cu}(\mathrm{I})_{\text {(sol.) }} \\
& \left(\mathrm{L}_{\mathrm{ox}}\right)_{\mathrm{n}} \mathrm{Cu}(\mathrm{I})_{(\mathrm{sol} .)} \rightleftarrows\left(\mathrm{L}_{\mathrm{ox}}\right)_{\mathrm{n}} \mathrm{Cu}(\mathrm{I})_{(\text {ads. }} \\
& \text { Accumulation step } \\
& \left(\mathrm{L}_{\mathrm{ox}}\right)_{\mathrm{n}} \mathrm{Cu}(\mathrm{I})_{\text {(ads. })}+\mathrm{e}^{-} \stackrel{\mathrm{Hg}}{\longrightarrow} \mathrm{nL}_{\mathrm{ox}}+\mathrm{Cu}(\mathrm{Hg}) \\
& \text { Stripping step }
\end{aligned}
$$

where $\mathrm{L}_{\mathrm{ox}}$ and $\mathrm{n}$ are ligand (thioguanine or captopril) in the oxidation form and coordination number of the complexes, respectively. According to the above results the formation constants for thioguanine and captopril complexes are $4.9( \pm 0.3) \times 10^{15}$ and $2.5( \pm 0.2) \times 10^{16}$, respectively.

\section{Optimization of the variables}

In our experiments, we studied the effect of instrumental 
and chemical factors including $\mathrm{pH}, \mathrm{Cu}$ (II) concentration, accumulation potential, accumulation time and scan rate on the peak currents.

Figure 3 illustrates the dependence of the peak currents on $\mathrm{pH}$ of the solution containing both captopril and thioguanine. The results show that the peak currents were increased from $\mathrm{pH} 2$ to 3.5. However, by increasing $\mathrm{pH}$ from 3.5 to 6.0 the peak currents decreased due to decrease of the stability of captopril- $\mathrm{Cu}(\mathrm{I})$ and thioguanine$\mathrm{Cu}(\mathrm{I})$ complexes. So a $\mathrm{pH}$ of 3.5 was selected for further optimization steps.

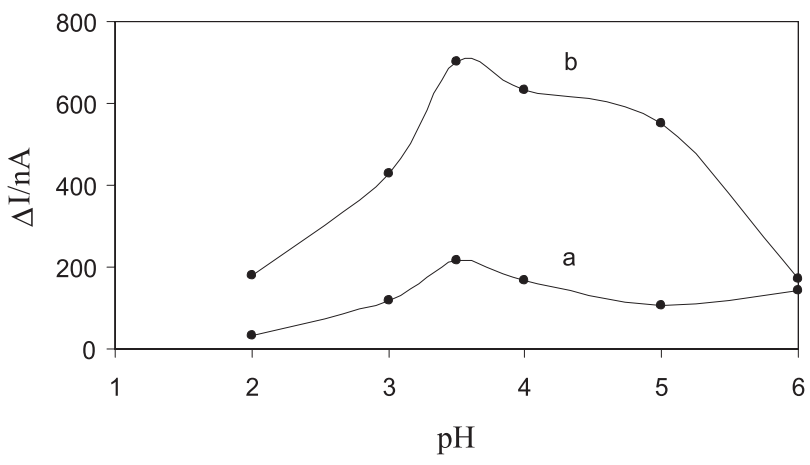

Figure 3. Effect of $\mathrm{pH}$ on the adsorptive cathodic stripping peak currents of $50 \mathrm{nmol} \mathrm{L}^{-1}$ and $100 \mathrm{nmol} \mathrm{L}^{-1}$ of (a) captopril and (b) thioguanine, respectively. Conditions: $20 \mathrm{ng} \mathrm{mL}^{-1}$ copper(II), scan rate of $60 \mathrm{mV} \mathrm{s}^{-1}$ and accumulations time of $60 \mathrm{~s}$ at $-0.30 \mathrm{~V}$ vs. $\mathrm{Ag} / \mathrm{AgCl}$ reference electrode.

The dependence of the peak currents on the copper(II) concentration was evaluated over the range of 0.0 to $50 \mathrm{ng}$ $\mathrm{mL}^{-1}$ copper(II) for $50 \mathrm{nmol} \mathrm{L^{-1 }}$ captopril and $100 \mathrm{nmol}$ $\mathrm{L}^{-1}$ thioguanine at $\mathrm{pH} 3.5$. The results (Figure 4) showed that the peak current values were maximal for copper(II)

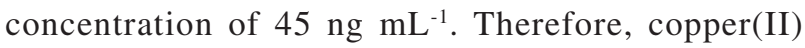
concentration of $45 \mathrm{ng} \mathrm{mL}^{-1}$ was selected for the study.

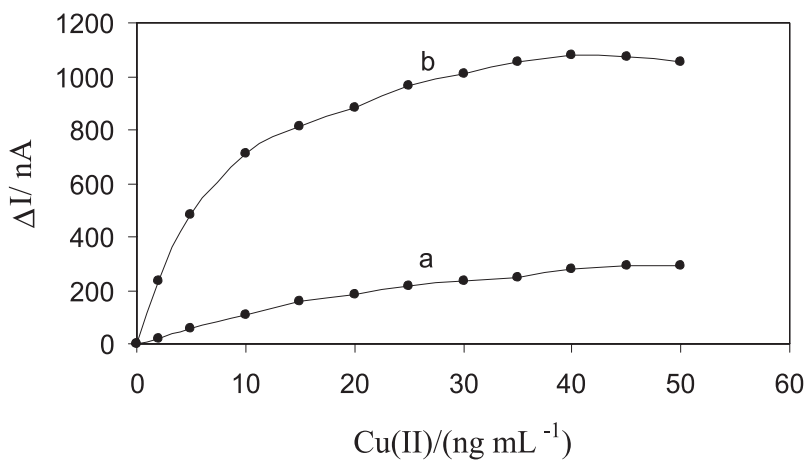

Figure 4. Influence of copper(II) concentration on the peak currents. Conditions: a) $50 \mathrm{nmol} \mathrm{L}^{-1}$ captopril in B-R buffer ( $\mathrm{pH}=3.5$ ); b) $100 \mathrm{nmol} \mathrm{L}^{-1}$ thioguanine in $\mathrm{B}-\mathrm{R}$ buffer $(\mathrm{pH}=3.5)$. Other conditions are: accumulation potential, $-0.30 \mathrm{~V}$; accumulation time, $60 \mathrm{~s}$; and scan rate, $60 \mathrm{mV} \mathrm{s}^{-1}$.
Figure 5 shows the dependence of the adsorptive peak currents on the accumulation potential over the range of +0.20 to $-0.60 \mathrm{~V}$ (vs. $\mathrm{Ag} / \mathrm{AgCl}$ ) for $50 \mathrm{nmol} \mathrm{L}{ }^{-1}$ captopril and $100 \mathrm{nmol} \mathrm{L}^{-1}$ thioguanine at $\mathrm{pH} 3.5$ and copper(II) concentration of $45 \mathrm{ng} \mathrm{mL}^{-1}$. The results show that the peak currents increase by changing accumulation potential from +0.20 to $-0.10 \mathrm{~V}$. More negative accumulation potentials cause decreasing the peak currents. This is due to the fact that for more negative potentials, $\mathrm{Cu}$ (II) reduced directly to $\mathrm{Cu}(\mathrm{Hg})$ on the surface of the electrode, whereas to get higher sensitivity, $\mathrm{Cu}(\mathrm{I})$ is needed to make complexes with the thiols. In addition, due to the existence of two separate peak potential and higher sensitivity for captopril and thioguanine in the accumulation potential of $-0.10 \mathrm{~V}$, accumulation potential of $-0.10 \mathrm{~V}$ was selected for simultaneous determination of the two thiols.

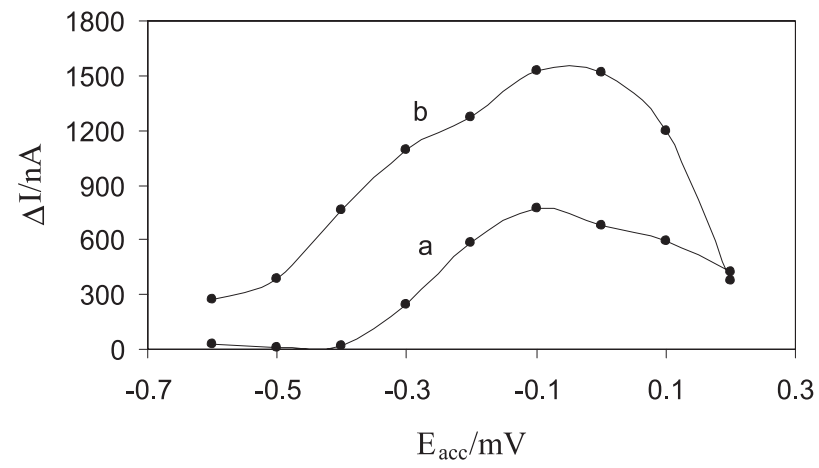

Figure 5. Influence of accumulation potential on the peak currents of (a) $50 \mathrm{nmol} \mathrm{L}^{-1}$ captopril and (b) $100 \mathrm{nmol} \mathrm{L}^{-1}$ thioguanine. Conditions: $\mathrm{Cu}$ (II), $45 \mathrm{ng} \mathrm{mL}^{-1}$; accumulation time, $60 \mathrm{~s} ; \mathrm{pH}=3.5$; and scan rate, $60 \mathrm{mV} \mathrm{s}^{-1}$.

Figure 6 shows the dependence of the adsorptive peak currents on the accumulation time in the presence of $50 \mathrm{~mol} \mathrm{~L}^{-1}$ captopril and $100 \mathrm{nmol} \mathrm{L}{ }^{-1}$ thioguanine

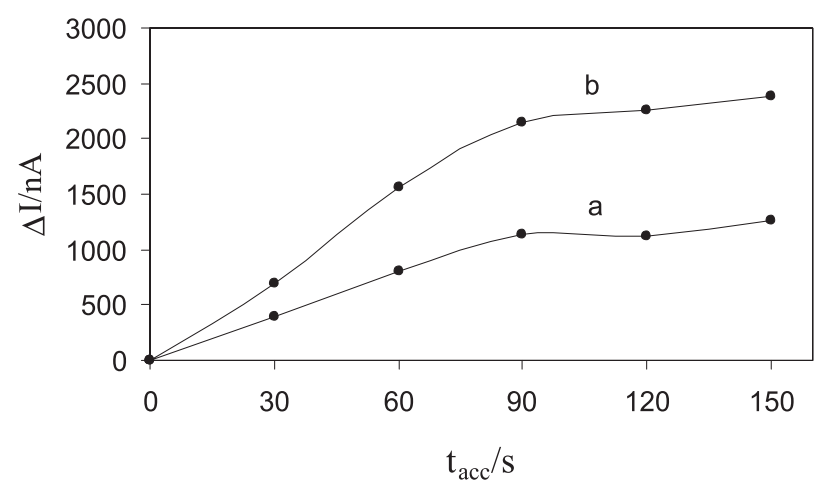

Figure 6. Influence of accumulation time on the peak currents of a) $50 \mathrm{nmol} \mathrm{L} \mathrm{L}^{-1}$ captopril and b) $100 \mathrm{nmol} \mathrm{L}^{-1}$ thioguanine. Conditions: $\mathrm{Cu}(\mathrm{II}), 45 \mathrm{ng} \mathrm{mL} \mathrm{m}^{-1}$; accumulation potential, $-0.10 \mathrm{~V}$; $\mathrm{pH}, 3.5$; and scan rate, $60 \mathrm{mV} \mathrm{s}^{-1}$. 
Table 1. Characteristics of the calibration plots of captopril and thioguanine under the optimum conditions

\begin{tabular}{|c|c|c|c|c|c|c|}
\hline \multirow[t]{2}{*}{ Species } & \multicolumn{2}{|c|}{ Regression equation* } & \multirow[t]{2}{*}{$\mathrm{r}$} & \multirow[t]{2}{*}{$\mathrm{LDR}^{* *}$} & \multirow[t]{2}{*}{$\mathrm{LOD}^{* *}$} & \multirow[t]{2}{*}{$\mathrm{LOQ}^{* *}$} \\
\hline & Slope (b) & Intercept (a) & & & & \\
\hline \multirow[t]{2}{*}{ Captopril } & $23.974( \pm 2.2)$ & $11.66( \pm 12.7)$ & 0.997 & $0.5-10$ & 0.3 & 0.5 \\
\hline & $17.07( \pm 3.2)$ & $113.96( \pm 21.4)$ & 0.997 & $10-100$ & & \\
\hline \multirow[t]{3}{*}{ Thioguanine } & $38.68( \pm 2.9)$ & $33.14( \pm 9.7)$ & 0.994 & $0.15-10$ & 0.08 & 0.15 \\
\hline & $20.17( \pm 0.9)$ & $262.47( \pm 37.8)$ & 0.990 & $10-100$ & & \\
\hline & $8.10( \pm 2.1)$ & $1482.9( \pm 44.6)$ & 0.990 & $100-180$ & & \\
\hline
\end{tabular}

$* \mathrm{I}_{\mathrm{p}}(\mathrm{nA})=\mathrm{bC}\left(\mathrm{nmol} \mathrm{L} \mathrm{L}^{-1}\right)+\mathrm{a} ; * * \mathrm{nmol} \mathrm{L}{ }^{-1}$

at $\mathrm{pH} 3.5$ and copper(II) concentration of $45 \mathrm{ng} \mathrm{mL}^{-1}$. As shown in Figure 6, by increasing accumulation time up to $90 \mathrm{~s}$ lead to increasing the peak current for both captopril-copper(I) and thioguanine-copper(I) complexes. As the accumulation time increases ( $>90 \mathrm{~s})$, the peak currents tend to leveled off, showing that the adsorptive equilibrium is reached above these times. According to the above results, an accumulation time of $90 \mathrm{~s}$ was selected for further studies.

The influence of potential scan rate on the reduction peak currents of the captopril-copper(I) and thioguaninecopper(I) complexes were also studied under the optimized conditions containing $45.0 \mathrm{ng} \mathrm{mL}^{-1}$ copper(II), $\mathrm{pH} 3.5$, accumulation potential of $-0.10 \mathrm{~V}$ and accumulation time of $90 \mathrm{~s}$ in the present of $50 \mathrm{nmol} \mathrm{L}^{-1}$ captopril, $100 \mathrm{nmol} \mathrm{L}^{-1}$ thioguanine. As it is expected in differential pulse voltammetry, the results showed that the peak currents for captopril and thioguanine are independent on scan rate in the range of 10 to $90 \mathrm{mV} \mathrm{s}^{-1}$. Therefore, a scan rate of $60 \mathrm{mV} \mathrm{s}^{-1}$ was selected for further studies.

Accordingly, the established optimal operational parameters of the proposed differential pulse adsorptive cathodic stripping voltammetric procedure were B-R buffer at $\mathrm{pH} 3.5$ as a supporting electrolyte, copper(II) concentration of $45 \mathrm{ng} \mathrm{mL}^{-1}$, accumulation potential of $-0.10 \mathrm{~V}$ (versus $\mathrm{Ag} / \mathrm{AgCl}$ ), accumulation time of $90 \mathrm{~s}$, scan rate of $60 \mathrm{mV} \mathrm{s}^{-1}$ and pulse amplitude of $100 \mathrm{mV}$.

\section{Validation of the proposed analysis procedure}

The validation of the proposed method was examined via evaluation of the linear dynamic range (LDR), sensitivity, limit of detection (LOD), limit of quantitation (LOQ), repeatability and selectivity. Under the optimum conditions, the corresponding calibration graphs were linear over the concentration ranges reported in Table 1 . The LOD and LOQ were estimated as LOD $=\left(B+3 \mathrm{~S}_{\mathrm{B}}\right) / \mathrm{b}$ and LOQ $=$ $\left(\mathrm{B}+10 \mathrm{~S}_{\mathrm{B}}\right) / \mathrm{b},{ }^{38}$ where $\mathrm{B}, \mathrm{S}_{\mathrm{B}}$ and $\mathrm{b}$ are current of the blank, standard deviation of the blank and slope of the calibration curve, respectively. The estimated values of LOD and LOQ (Table 1) show an improvement in sensitivity of the proposed procedure for quantification of captopril and thioguanine compared to that of the reported methods. ${ }^{8-34}$

The relative standard deviations for five replicates analyses of $20 \mathrm{nmol} \mathrm{L}^{-1}$ captopril and thioguanine are $2.5 \%$ and $2.1 \%$, respectively.

An attractive feature of an analytical procedure is its relative freedom from interferences. The selectivity of the proposed procedure for the assay of captopril and thioguanine was identified by studying the effect of excipients that often accompany with captopril and thioguanine in pharmaceutical formulations. Samples containing $50 \mathrm{nmol} \mathrm{L}^{-1}$ captopril and/ or thioguanine in the absence and presence of excipients were analyzed by means of the proposed procedure. Tolerance limit was defined as the concentrations which give an error of $\leq 5 \%$ in the determination of captopril and/ or thioguanine. The effects of all examined compounds at several molar ratios over captopril and thioguanine on the measured analytical concentration are given in Table 2 . The results show no significant interference from excipients. This is due to the fact that in acidic media, $\mathrm{pH}(\sim 3.5)$, many organic substances can not make complex with $\mathrm{Cu}(\mathrm{I})$ in aqueous media.

Table 2. Maximum tolerable concentration of interfering species in the present of $50 \mathrm{nmol} \mathrm{L}^{-1}$ captopril and/or $50 \mathrm{nmol} \mathrm{L}^{-1}$ thioguanine

\begin{tabular}{lc}
\hline Species & Tolerance limit (mol/mol) \\
\hline$L$-Serine, Alanine, $L$-Asparag- & \\
ine, $L$-Phenylalanine, Glycine, & \\
$L$-Threonine, $L$-Proline, Histi- & \\
dine, Methionine, Ascorbic Acid, & 1000 \\
$D L$-Glucose, Lactose, Saccarose, & \\
Fructose, Benzoic acid, Methanol, & \\
Ethanol, Urea, Fe(II), Fe(III), & \\
$\mathrm{NO}_{2}-$ & 100 \\
\hline Cystine & 50 \\
\hline$D L$-Tryptophan & 10 \\
\hline Glutathione, Cysteine &
\end{tabular}


Table 3. Determination of captopril and thioguanine in synthetic and real samples $(n=4)$

\begin{tabular}{|c|c|c|c|c|c|c|}
\hline \multirow{2}{*}{ Sample } & \multicolumn{2}{|c|}{ Added $\left(\mathrm{nmol} \mathrm{L} \mathrm{L}^{-1}\right)$} & \multicolumn{2}{|c|}{ Found $\left(\mathrm{nmol} \mathrm{L} \mathrm{L}^{-1}\right)$} & \multicolumn{2}{|c|}{ Recovery (\%) } \\
\hline & CPL & TGA & $\mathrm{CPL}$ & TGA & $\mathrm{CPR}$ & TGA \\
\hline Synthetic 1 & 10.0 & 10.0 & $9.3( \pm 0.5)$ & $9.2( \pm 0.4)$ & 93.0 & 92.0 \\
\hline Synthetic 1 & 20.0 & 20.0 & $19.8( \pm 1.2)$ & $19.0( \pm 0.9)$ & 99.0 & 95.0 \\
\hline Synthetic 3 & 40.0 & 40.0 & $43.3( \pm 2.5)$ & $43.2( \pm 1.9)$ & 108.2 & 108.0 \\
\hline Synthetic 4 & 100.0 & 100.0 & $100.0( \pm 5.6)$ & $94.4( \pm 4.8)$ & 100.0 & 94.4 \\
\hline Synthetic 5 & 100.0 & 10.0 & $95.0( \pm 6.7)$ & $9.8( \pm 0.38)$ & 95.0 & 98.0 \\
\hline Synthetic 6 & 10.0 & 100.0 & $9.9( \pm 0.61)$ & $108.7( \pm 7.8)$ & 99.0 & 108.7 \\
\hline Tablet $^{\mathrm{a}}$ & - & - & $26.6( \pm 1.4)$ & - & 106.4 & - \\
\hline Tablet $^{\mathrm{b}}$ & - & - & $48.2( \pm 2.9)$ & - & 96.4 & - \\
\hline Tablet $^{\mathrm{c}}$ & - & - & ---- & $37.8( \pm 3.2)$ & - & 94.5 \\
\hline \multirow[t]{3}{*}{ Human serum } & - & - & $<\mathrm{LOD}^{\mathrm{d}}$ & $<$ LOD & - & - \\
\hline & 10.0 & 10.0 & $8.3( \pm 0.9)$ & $9.9( \pm 0.6)$ & 83.0 & 99.0 \\
\hline & 30.0 & 30.0 & $28.2( \pm 1.1)$ & $30.0( \pm 2.3)$ & 94.0 & 100.0 \\
\hline \multirow[t]{3}{*}{ Whole Blood ${ }^{e}$} & - & - & $21.5( \pm 1.4)$ & $58.7( \pm 4.1)$ & - & - \\
\hline & 4.0 & 8.0 & $25.6( \pm 0.9)$ & $66.5( \pm 4.8)$ & 102.5 & 97.5 \\
\hline & 8.0 & 16.0 & $29.3( \pm 1.2)$ & $3.9( \pm 5.1)$ & 97.5 & 95.0 \\
\hline
\end{tabular}

CPL: Captopril; TGA: Thioguanine; ${ }^{a}$ Labeled: Captopril $(25 \mathrm{mg})$ for each tablet; ${ }^{\mathrm{b} L a b e l e d: ~ C a p t o p r i l ~}(50 \mathrm{mg})$ for each tablet; ${ }^{\mathrm{c}}$ Labeled: Thioguanine $(40$ $\mathrm{mg}$ ) for each tablet; ${ }^{\mathrm{d}}$ Limit of detection; ${ }^{\mathrm{e}} \mathrm{Blood}$ samples were taken from people who had heart failure and leukemia together.

\section{Application}

To investigate the applicability of the proposed method for the stripping voltammetric determination of captopril and thioguanine, the method was applied to the determination of captopril and thioguanine in synthetic mixed samples, tablets and human serum by standard addition method. The results are given in Table 3. As it is obvious, the results obtained by the proposed method reveal the capability of the method for determination of captopril and thioguanine in pharmaceutical and biological fluids without considerable error.

\section{Conclusion}

The present study demonstrates that the adsorptive stripping voltammetric analysis of captopril and thioguanine in the presence of copper(II) is a good method for determination of ultra trace amount of captopril and thioguanine. According to our knowledge, it is the first method that offered for simultaneous determination of captopril and thioguanine in real samples. In conclusion, the above system, offers a practical potential for selective trace determination of captopril and thioguanine, high sensitivity and simplicity in the presence of amino acids, good repeatability, suitable speed (less than 6 min for each test), good accuracy, and lower detection limits that have not been presented together in the previously reported literature.

\section{Acknowledgments}

The authors gratefully acknowledge the support of this work by Research Council of Isfahan University of Technology (IUT). Also the assistance of Omid Hospital staff for collecting patients' blood is gratefully acknowledged.

\section{References}

1. Florey, K. Analytical Profiles of Drug Substances, Academic Press: New York, 1982.

2. Ioannides, X.; Economou, A.; Voulgaropoulos, A.; J. Pharm. Biomed. Anal., 2003, 33, 309.

3. Goodman, A.; Goodman, L. S.; Rall, T. W.; Murad, F.; Las Bases Farmacologicas de la Terapeutica, Panamericana: Madrid, 1989.

4. Korolkovas, A.; Essentials of Medicinal Chemistry, Wiley: New York, 1988.

5. Katazung, B. G.; Basic \& Clinical Pharmacology, PrenticeHall: New Jersey, 1992.

6. Nelson, J. A.; Carpenter, J. W.; Rose, L. M.; Adamson, D. Y.; Cancer Res. 1975, 35, 2872.

7. Barek, J.; Berka, A.; Zima, J.; Talanta 1985, 32, 987. 
8. Ouyang, J.; Baeyens, W. R. G.; Delanghe, J.; Van der Weken, G.; Van Daele, W.; de Keukeleire, D.; Garcia Campana, A. M.; Anal. Chim. Acta 1999, 386, 257.

9. Tache, F.; Farca, A.; Medvedovici, A.; David, V.; J. Pharm. Biomed. Anal. 2002, 28, 549.

10. Huang, T.; He, Z.; Yang, B.; Shao, L.; Zheng, X.; Duan, G.; J. Pharm. Biomed. Anal. 2006, 41, 644.

11. Mirza, T.; Tan, H. S. I.; J. Pharm. Biomed. Anal. 2001, 25, 39.

12. El Walily, A. F. M.; Razak, O. A.; Belal, S. F.; Bakry, R. S.; J. Pharm. Biomed. Anal. 1999, 21, 439.

13. Arroyoa, C.; Calulla, C. L.; Capdevilaa, L. G.; Gichb, I.; Barbanojb, M.; Bonala, J.; J. Chromatogr. B 1997, 688, 339.

14. Amini, M.; Zarghi, A.; Vatanpour, H.; Pharm. Acta. Helvetiae 1999, 73, 303.

15. Bahmaeia, M.; Khosravi, A.; Zamiri, C.; Massoumi, A.; Mahmoudian, M.; J. Pharm. Biomed. Anal. 1997, 15, 1181.

16. Askal, H. F.; Talanta 1991, 38, 1155.

17. Emara, M. K.; Mohamed, I. A. M.; Askal, F. H.; Anal. Lett. 1993, 26, 2385.

18. Karlicek, R.; Solich, P.; Pharmazie 1998, 53, 549.

19. Tzanavaras, P.D.; Themelis, D.G.; Economou, A.; Theodoridis, G.; Talanta 2002, 57, 575.

20. Imai, K.; Toyoka, T., Watanabe, Y.; Anal. Biochem. 1983, 128, 471.

21. Thomas, A.D.; Talanta 1976, 23, 383.

22. Russell, J. D.; Rubenstein, L.; Anal. Biochem. 1996, 242, 136.

23. Zhang, Z. D.; Baeyens, W. R. G.; Zhang, X. R.; Van der Weken, G.; J. Pharm. Biomed. Anal. 1996, 14, 939.

24. Erdmann, G. R.; Steury, J. C.; Carleton, B. C.; Stafford, R. J.; Bostrom, B. C.; Canafax, D. M.; J. Chromatogr. Biomed. Appl. 1991, 571, 149 .
25. Fraga, P. M.; Gonzalez, E.B.; Medel, A.S.; Anal. Chim. Acta 1988, 212, 181.

26. Pike, M.G.; Franklin, C. L.; Mays, D. C.; Lipsky, J. J.; Lowry, P. W.; Sandborn, W. J.; J. Chromatogr. B 2001, 757, 1.

27. Wang, W.; Wang, S. F.; Xie, F.; Sens. Actuators, B 2006, 120, 238.

28. Stefan, R. I.; Van Staden, J. F.; Aboul-Enein, H. Y.; Talanta 2000, 51, 969.

29. Siangproh, W.; Ngamukot, P.; Chailapakul, O.; Sens. Actuators, B 2003, 91, 60 .

30. Wakabayashi, H.; Yamato, S.; Nakajima, M.; Shimada, K.; J. Pharm. Biomed. Anal. 1994, 12, 1147.

31. Stefan, R. I.; Van Staden, J. F. H. ; Aboul-Enein, Y.; Biosens. Bioelectron. 2000, 15, 1 .

32. Palomeque, M. E.; Fernandez Band, B. S.; J. Pharm. Biomed. Anal. 2002, 30, 547.

33. Parham, H.; Zargar, H.B., Talanta 2005, 65, 776.

34. Passamonti, P.; Bartocci, V.; Pucciarelli, F.; J. Electroanal. Chem. Interf. Electrochem. 1987, 230, 99.

35. Torreggiani, A.; Taddei, P.; Tosi, M. R.; Tugnoli, V.; J. Mol. Struct. 2001, 565, 347.

36. Gao, X. Handbook on the Physics and Chemistry of Rare Earths; Elsevier: Amsterdam, 1986.

37. Hajian, R.; Shams, E.; J. Iran. Chem. Soc. 2006, 3, 32.

38. Miller, J. C.; Miller, J. N. Statistics for Analytical Chemistry; $4^{\text {th }}$ ed., Ellis-Horwood: New York, 1994.

Received: July 4, 2007

Web Release Date: February 7, 2008 